\title{
RESENHA
}

\section{Relações entre pais e filhos e mundo do trabalho: compatibilidade ou incompatibilidade?}

\author{
Fernanda Ax Wilhelm \\ Olga Mitsue Kubo \\ Universidade Federal de Santa Catarina
}

Mizhari, Beatriz Gang (2004). A relação pais e filhos hoje: a parentalidade e as transformações no mundo do trabalho. Rio de Janeiro: PUC e São Paulo: Loyola. (151 p.)

Trabalho e família: ruptura nas práticas de cuidados? Quais as repercussões das transformações no mundo do trabalho sobre as relações entre pais e filhos? Beatriz Gang Mizrahi, autora do livro "A relação pais e filhos hoje: a parentalidade e as transformações no mundo do trabalho", baseada em sua dissertação de mestrado, busca investigar a relação entre as mudanças advindas da esfera produtiva e suas implicações na esfera familiar, principalmente no que diz respeito às relações entre pais e filhos, tendo como referencial a família de classe média urbana. A obra merece ser lida na perspectiva de analisar a interface entre esses dois fenômenos "mundo do trabalho" e "mundo familiar", num contexto em que as transformações são constantes. Vale a pena conferir!

O livro é destinado a psicólogos que atuam no campo educacional, clínico e organizacional, pedadogos e educadores que atuam em organizações de ensino, e aos pais que vivenciam essa realidade e muitas vezes sentem-se confusos com a educação dos filhos devido à necessidade de manterem uma dupla jornada como trabalhadores e como pais. A leitura do livro proporciona, tanto aos profissionais que atuam com crianças quanto aos pais, refleções sobre questões referentes às constantes mudanças no mundo do trabalho que incidem sobre as práticas de cuidados com os filhos como, por exemplo, a sobrecarga de atividades direcionadas às crianças.

Ao longo do livro, a autora expõe de forma simples e objetiva um exame pertinente sobre a importância de uma cisão entre o espaço público e o privado, e alerta para a sobrecarga vivenciada na esfera profissional pelos pais inseridos nas organizações de trabalho. Inserir-se em processos produtivos de maneira geral, pressupõe níveis de eficiência cada vez maior no trabalho, compatível com as exigências do sistema capitalista. Tais exigências acarretam aos pais preocupações como: possibilidade do desemprego, necessidade de qualificação permanente e aceitação de sobrecarga de trabalho. Em algumas situações, anterior ao nascimento do bebê, ainda no momento de gestação, direitos como licença maternidade e dispensa por ocasião de adoecimento do filho ocasionam preocupações para os futuros pais, mediante o receio de perder o emprego. É perceptível que aspectos como esses mencionados interfiram diretamente nas práticas de cuidados de pais em relação aos seus filhos, alterando até a própria concepção dos pais sobre o que é ser criança.

A preocupação cada vez mais presente nos tempos atuais do século XXI, com a preparação das pessoas para responder às exigências do mundo do trabalho cada vez mais competitivo, tem repercutido sobre práticas dos pais com seus filhos de forma singular e crescente: a precoce profissionalização de seus filhos. A inserção dos filhos desde tenra idade em instituições como creches proporciona aos pais continuar suas atividades produtivas e, ao mesmo tempo, deixálos aos cuidados de especialistas que, diante de um suposto futuro incerto e desprotegido, terão como finalidade educativa incentivar a autonomia e independência dessas crianças. As atividades serão desempenhadas com o intuito de expor as crianças desde muito pequenas a diversos contextos de aprendizagem e a um bom desempenho escolar, visando sua futura inserção no mercado de trabalho.

Dentre as atividades pedagógicas exigidas pelos pais dessas organizações de ensino é de que sejam voltadas para a promoção de características como 
"serem inteligentes", "serem criativas" e "serem qualificadas". Da valorização dessas características pelos pais, decorre uma sobrecarga de atividades a serem cumpridas pelos filhos ao longo do dia: aulas de inglês, natação, informática, entre outras atividades. A organização escolar insere-se, portanto, de forma crescente na educação dos filhos, segundo a autora, com o objetivo de promover a padronização do indivíduo a sua futura dinâmica de trabalho, sem considerar sua idade precoce. Por meio de relatos de pais, citados com excelente pertinência ao longo da obra, é perceptível uma aparente aceleração no ritmo de desenvolvimento infantil, na qual a criança é exigida de várias formas, cada vez mais distante de seu papel mais importante: o de ser criança.

A partir da contribuição do pensamento proposto por Winicott, a autora propõe aos pais que estão inseridos no contexto de trabalho uma outra visão acerca do que é ser pai e mãe, a partir da imbricação entre as duas esferas (espaço público e privado). A autora destaca a importância dos adultos nos cuidados infantis, salientando a contribuição dos cuidados exclusivos nos primeiros anos de vida. Enfatiza os cuidados parentais como singulares, e não ditados por esferas públicas, principalmente no que diz respeito às organizações de trabalho, que, devido às exigências de produtividade e participação de seus empregados, exigem uma dedicação maior destes em relação a sua atuação nessas organizações. A obra se refere, portanto, à importância da forma particular de cuidar dos filhos para cada família, de acordo com concepções delimitadas pelos próprios pais.

Os cuidados com os filhos necessitam ter como referência uma relação baseada em laços afetivos estáveis entre pais e filhos. Cabe aos pais criarem seus filhos como experiência criativa, ou seja, que as práticas de cuidados sejam voltadas às suas experiências singulares, de acordo com cada dinâmica familiar. A autora salienta a importância de que os cuidados ocorram conforme o respeito às características de desenvolvimento dos filhos. É sabido que a relação acima mencionada não é comum. A autora sugere, portanto, a criação de um espaço, seja na instituição escolar, seja na clínica, que oportunize aos pais falar sobre seus incômodos em relação ao ambiente profissional e práticas de cuidados com seus filhos. Recomenda ainda que tais falas se transformem em reivindicações expostas para a sociedade como um todo, uma vez que considera que essa temática necessita ser discutida por todas as esferas da sociedade, provocando mudanças.

Por fim, esta é uma obra que apresenta uma pertinente reflexão sobre as relações entre pais e filhos e a inserção destes no universo do trabalho, sendo de grande valia para o avanço na produção de conhecimento sobre a relação entre práticas de cuidados e organizações de trabalho. A leitura do livro postula a importância de que as práticas de cuidados possam ser estabelecidas, promovendo o desenvolvimento sadio de crianças, na especificidade de sua infância e não seguir modelos que mais parecem linhas de produção "encaixando" estas, desde idades inicias, no desempenho e cumprimento de uma grande quantidade de atividades e obrigações com o objetivo de maximizar sua futura performance no processo produtivo. Vale a pena conferir!

\section{Sobre as autoras da Resenha:}

Fernanda Ax Wilhelm: Mestra em Psicologia pela Universidade Federal de Santa Catarina e Universidade do Oeste de Santa Catarina (mifer@softhouse.com.br)

Olga Mitsue Kubo: Doutora em Psicologia. Professora do Departamento de Psicologia da Universidade Federal de Santa Catarina (ok@cfh.ufsc.br) 